\title{
Date Fiber as a Constituent of Broiler Starter Diets
}

\author{
W. Al-Marzooki*, A. Al-Halhali, R. Al-Maqbaly, A. Ritchie, \\ K. Annamalai, and N.E. Forsberg
}
Department of Animal and Veterinary Sciences, College of Agriculture, Sultan Qaboos University, P.O. Box 34, Al Khod 123, Sultanate of Oman

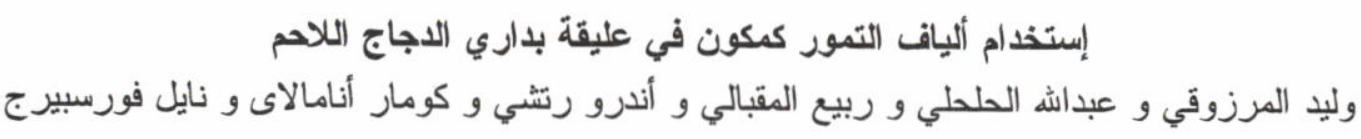

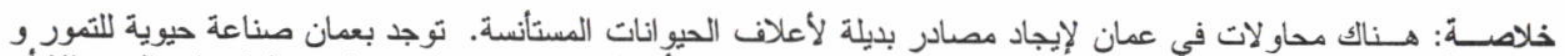

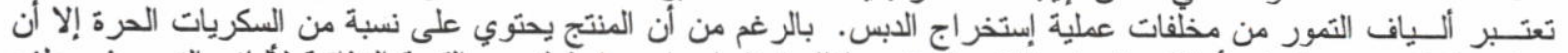

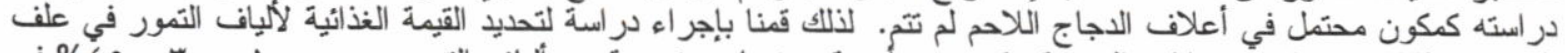

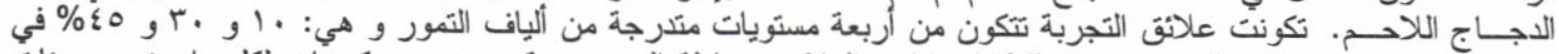

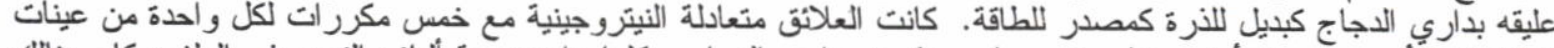

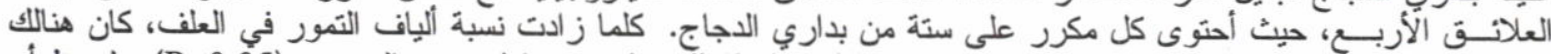

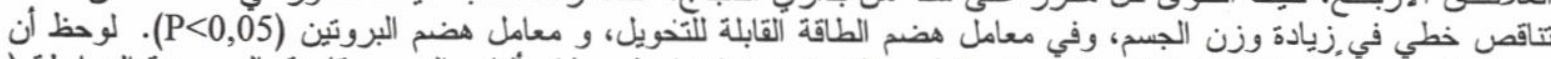

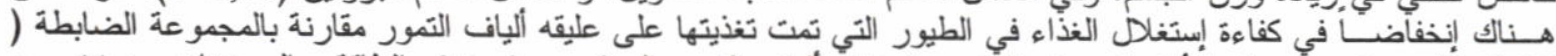

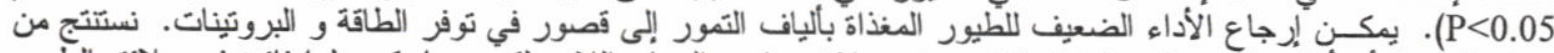

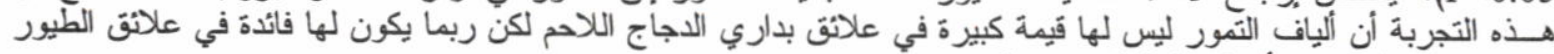

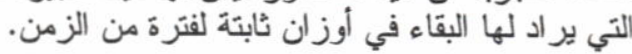

\begin{abstract}
In Oman, efforts are underway to find alternative sources of feed to support domestic livestock. The date industry thrives in Oman and one of its by-products is date fiber, a by-product of date syrup production. Although the product contains some free sugars, an evaluation of its potential in broiler diets has never been undertaken. Therefore, we conducted an experiment to investigate the value of date fiber in broiler chick diets. The experimental diets consisted of four graded levels of date fiber: $0,15,30$ and $45 \%$ in a broiler-starter ration replacing corn as an energy source. The diets were isonitrogenous. There were five replicates for each of the four diets and each replicate contained six broiler chicks. As date fiber percent increased in the dietary treatment, there were linear reductions in body weight gain, calculated apparent metabolizable energy (AMEn) content, and apparent protein digestibility $(\mathrm{P}<0.05)$. Poor feed utilization (i.e., reduced feed efficiency) was observed in birds fed date fiber diets compared to the control group $(\mathrm{P}<0.05)$. The poor performance of birds fed date fiber may be attributed to protein and energy limitations. We conclude that date fiber has no value in growing broiler diets. However, it may have utility in diets where a stable body weight is desirable.
\end{abstract}

Keywords: date fiber, alternative feed, livestock, broiler diet, chicken.

$\mathbf{O}^{\prime}$ man faces challenges in meeting its needs for high quality animal protein production. At present, $97 \%$ of broilers consumed in the country are imported and there is a large need to consider strategies by which broiler production may be enhanced. One way to accomplish this is to use local feed resources where possible.

The date industry in Oman is large and produces a variety of by-products. It has been estimated that the total area for date palm cultivars in the Sultanate of
Oman is about 36,000 ha and the number of trees is 8 million with annual production of approximately 172,000 tonnes of dates (Anonymous, 1997). The byproducts include palm fronds, date pits, waste dates and date fiber. Jumah et al. (1973), reported that date pits may be used in broiler diets at levels of up to $10 \%$ of the diet dry matter. However, at $15 \%$ of the diet, body weight was significantly lower and feed conversion higher. Other studies (Kamel et al., 1981; Vandepopulaire et al., 1995; Hussein et al., 1998) have

${ }^{*}$ Corresponding author. 
TABLE 1

Composition of dietary treatments containing 0, 15, 30, and 45\% Date fiber.

\begin{tabular}{crrrr}
\hline Ingredient & \multicolumn{4}{c}{ Diet } \\
\cline { 2 - 5 } & \multicolumn{1}{c}{1} & \multicolumn{1}{c}{2} & \multicolumn{1}{c}{3} & \multicolumn{1}{c}{4} \\
\hline Date fiber & \multicolumn{1}{c}{15.00} & 30.00 & 45.00 \\
Corn & 56.30 & 40.85 & 25.39 & 9.93 \\
Soybean meal (48\% CP) & 35.60 & 36.05 & 36.51 & 36.97 \\
Fat & 3.50 & 3.50 & 3.50 & 3.50 \\
Ground limestone & 1.70 & 1.70 & 1.70 & 1.70 \\
Calcium phosphate (20\% p) & 1.50 & 1.50 & 1.50 & 1.50 \\
Iodized salt & 0.30 & 0.30 & 0.30 & 0.30 \\
Vitamin:Mineral ${ }^{1}$ premix & 1.00 & 1.00 & 1.00 & 1.00 \\
Methionine & 0.12 & 0.12 & 0.12 & 0.12 \\
Analytical Values & & & & \\
Crude protein \% & 22.00 & 22.00 & 21.50 & 22.00 \\
Crude fiber \% & 3.60 & 4.70 & 6.70 & 7.50 \\
Gross energy (Mcal/kg) & 4.78 & 4.61 & 4.42 & 4.09 \\
\hline
\end{tabular}

The vitamin:mineral premix was obtained from Oman Flour Mills. Final concentrations of vitamins and minerals in the diet were: retinal $(0.016$ $\mathrm{MIU} / \mathrm{kg}$ ), cholecalciferol ( $0.003 \mathrm{MIU} / \mathrm{kg})$, tocopherol $(15 \mathrm{IU} / \mathrm{kg})$, menadione $(0.03 \mathrm{~g} / \mathrm{kg})$, thiamin $(0.001 \mathrm{~g} / \mathrm{kg})$, riboflavin $(0.007 \mathrm{~g} / \mathrm{kg})$, nicotinic acid $(0.4$ $\mathrm{g} / \mathrm{kg})$, pantothenic acid $(.11 \mathrm{~g} / \mathrm{kg})$, pyridoxine $(0.005 \mathrm{~g} / \mathrm{kg})$, biotin $(0.1$ $\mathrm{mg} / \mathrm{kg})$, folic acid $(0.002 \mathrm{~g} / \mathrm{kg}), \mathrm{B} 12(0.01 \mathrm{mg} / \mathrm{kg})$, cobalt $(0.25 \mathrm{ppm})$, copper $(15 \mathrm{ppm})$, iron $(0.025 \mathrm{~g} / \mathrm{kg})$, manganese $(.075 \mathrm{~g} / \mathrm{kg})$, molybdenum $(0.001$ $\mathrm{g} / \mathrm{kg})$, selenium $(0.015 \mathrm{ppm})$, zinc $(0.55 \mathrm{~g} / \mathrm{kg})$, zinc bacitracin $(0.2 \mathrm{~g} / \mathrm{kg})$ and ethoxyquin $(0.5 \mathrm{~g} / \mathrm{kg})$.

also reported that dates or date pits support growth performance in poultry and could be included at low levels such as 5,10 , and $15 \%$. No studies have been reported on the potential of date fiber in broiler diets.

Date fiber is manufactured in Oman and available at a reasonable price compared to other cereal grains. Date fiber is a by-product of the date syrup industry and may harbor sufficient soluble sugars to contribute significantly to bird energetic requirements. Hence, the objective of this study was to test the effect of feeding date fiber as an energy source.

\section{Materials and Methods}

One hundred and sixty commercial strain broiler chicks were obtained from a local hatchery at one day of age. They were housed in an electrically heated battery brooder and 24 hours of light were provided. Feed and water were provided ad libitum. Percentage diet composition and calculated nutrient content are presented in Table 1. A commercial source of date fiber in Oman was purchased from Oman Tamoor (Rusayl, Sultanate of Oman). The four dietary treatments consisted of four levels of date fiber, $0,15,30$, and $45 \%$ replacing corn as an energy source and the diets were isonitrogenous ( $22 \%$ crude protein). There were five replicates for each of the four dietary treatments and each replicate cage contained eight broiler chicks. The control diet (Treatment 1, Table 1) was used to feed all chicks from 1-3 days of age in order to allow enough time to reduce any variation of nutrient absorption from yolk residue among the chicks. From each replicate cage, six chicks out of eight within the same range of body weight were introduced to experimental diets on day 4 of age and were fed daily for a period of 25 days. Body weight and feed intake were determined for the duration of the study. Another measurement criteria included dietary $\mathrm{AME}_{\mathrm{n}}$ (Sibbald, 1986) which was undertaken when birds were 8-11 days of age. All samples of feed and excreta were ground to pass through a $1 \mathrm{~mm}$ screen prior to assay for determination of moisture content by drying in an oven at $60^{\circ} \mathrm{C}$ overnight. Nitrogen content was determined using a Tecator Kjeltec Auto 1030 Analyzer and gross energy content was determined by a Gallenkamp Ballistic Bomb Calorimeter (Model CBB-330). Methods used for feed analysis and excreta analysis were standard AOAC procedures (AOAC, 1980). The data were subjected to regression analysis using the PROC REG procedure of Statistical Analysis Systems (SAS Institute, 1991). An alpha level of $5 \%$ was adopted to indicate statistical significance for all treatments.

\section{Results and Discussion}

Analytical values for protein and fiber are shown in Table 1. The formulations were very close to isonitrogenous with Diets 1-4 containing nearly $22 \%$ crude protein. Crude fiber (CF) of the four diets increased with date fiber content.

Effects of feeding date fiber on performance are shown in Table 2. Although date fiber did not significantly reduce feed intake $(P>0.05)$, it clearly reduced performance of the birds. Addition of date fiber to broiler diets linearly suppressed $(\mathrm{P}<0.05)$ body weight gain and apparent protein digestibility of chicks fed these diets compared to the control diet. Body weight gain was reduced by $15 \%, 28 \%$ and $33 \%$ by increasing levels of $15 \%, 30 \%$ and $45 \%$ date fiber, respectively $(\mathrm{P}<0.05)$. In addition, the feed conversion

\section{TABLE 2}

Nitrogen corrected apparent metabolizable energy for broiler chicks from 8-11 days of age.

\begin{tabular}{ccc}
\hline Dietary Treatment & Chicks $^{1}$ & $\mathrm{AME}_{\mathrm{n}}{ }^{2} \mathrm{kcal} / \mathrm{kg}$ \\
\hline Omani Date Fiber Level & & \\
None & 30 & $2825^{\mathrm{a}}$ \\
$15 \%$ & 30 & $2598^{\mathrm{a}}$ \\
$30 \%$ & 30 & $2100^{\mathrm{b}}$ \\
$45 \%$ & 30 & $1827^{\mathrm{c}}$ \\
Linear Regression & $* *$ & \\
MSE & & 193.12 \\
\hline
\end{tabular}

$\overline{a, b, c}$ Values with different superscript letters are significantly different $(\mathrm{P}<0.05)$.

$\mathrm{AME}_{\mathrm{n}}=$ Apparent metabolizable energy.

MSE $=$ Mean Square Error. 


\section{DATE FIBER AND BROILER STARTER DIETS}

\section{TABLE 3}

Effect of use of date fiber on performance of broiler chicks from 4-25 days of age.

\begin{tabular}{|c|c|c|c|c|}
\hline Dietary Treatment & $\begin{array}{c}\mathrm{FI}^{1} \\
\mathrm{~g} / \mathrm{bird}\end{array}$ & $\begin{array}{l}\text { BWG }^{2} \\
\text { g/bird }\end{array}$ & $\begin{array}{c}\mathrm{FCR}^{3} \\
\mathrm{~g} \mathrm{feed/} \\
\mathrm{g} \text { gain }\end{array}$ & $\begin{array}{c}\mathrm{APD}^{4} \\
\%\end{array}$ \\
\hline \multicolumn{5}{|c|}{ Omani Date Fiber Level } \\
\hline None & $755^{\mathrm{a}}$ & $440^{\mathrm{a}}$ & $1.72^{d}$ & $58.8^{\mathrm{ab}}$ \\
\hline $15 \%$ & $738^{\mathrm{a}}$ & $375^{b}$ & $1.97^{\mathrm{c}}$ & $59.9^{\mathrm{a}}$ \\
\hline $30 \%$ & $710^{\mathrm{a}}$ & $316^{\mathrm{c}}$ & $2.25^{b}$ & $53.3^{c^{\prime}}$ \\
\hline $45 \%$ & $722^{\mathrm{a}}$ & $293^{c}$ & $2.47^{\mathrm{a}}$ & $49.6^{c}$ \\
\hline Linear Regression & NS & $* *$ & $* *$ & $* *$ \\
\hline $\mathrm{MSE}^{5}$ & & 26.3 & 0.091 & 3.52 \\
\hline $\begin{array}{l}\mathrm{a}, \mathrm{b}, \mathrm{c} \text { Values with differe } \\
(\mathrm{P}<0.05) . \\
\mathrm{NS}=\text { Not significant }(\mathrm{P} \\
{ }^{1} \mathrm{FI}=\text { Feed Intake (gram } \\
{ }^{2} \mathrm{BWG}=\text { Body Weight } \\
{ }^{3} \mathrm{FCR}=\text { Feed Conversio } \\
{ }^{4} \mathrm{APD}=\text { Apparent Prote } \\
{ }^{5} \mathrm{MSE}=\text { Mean Square }\end{array}$ & $\begin{array}{l}\text { superscr } \\
.05 \text { ). } \\
\text { ird, entir } \\
\text { (gain p } \\
\text { atio. } \\
\text { igestibil }\end{array}$ & $\begin{array}{l}\text { ady). } \\
\text { rd, ent }\end{array}$ & significa & different \\
\hline
\end{tabular}

ratio (feed/gain) was significantly increased by $14 \%$, $31 \%$, and $44 \%$ by diets containing the same levels of date fiber $(\mathrm{P}<0.05)$. Apparent protein digestibility was reduced by inclusion of both $30 \%$ and $45 \%$ date fiber in the diet. Apparent protein digestibility in the control diet was $58.8 \%$. This was reduced by $9.3 \%$ (to $53.3 \%$ ) by the inciusion of $30 \%$ fiber in the diet and by $15.6 \%$ (to $49.6 \%$ ) by the inclusion of $45 \%$ fiber in the diet $(\mathrm{P}<0.05$; Table 2).

To gain insight into the energetic value of date fiber, a digestibility trial was conducted with the broilers from Days 8-11 of the trial (Table 3). At this time, the birds were 11-14 days of age. Inclusion of date fiber at 30 and $45 \%$ of the diet (at the expense of corn) reduced dietary Apparent Metabolizable Energy (AMEn) values $(\mathrm{P}<0.05$; Table 3$)$. Differences in diet AMEn value among birds receiving $15 \%$ date fiber were not significant $(\mathrm{P}>0.05)$. Based on extrapolation, we estimate the AMEn value of date fiber to be low (ca. $500 \mathrm{kcal} / \mathrm{g}$ ). These data indicate that date fiber is not equivalent to conventional concentrates for growing broiler chickens and residual sugar content to be inadequate to support the high rates of growth which are characteristic of modern poultry breeds.

It can be concluded that date fiber at levels of 15 , 30 and $45 \%$, depressed $(P<0.05)$ growth performance of broiler chicks (Table 3). A possible reason for the poor performance of date fiber-fed chicks is the higher fiber content of their diets, low ME value and lower protein digestibility. Evidently, residual sugars are very limited in the date fiber product. Although growth was suppressed by date fiber, it might be used at lower levels (i.e., less than $15 \%$ ) to partially replace corn, especially at times of high concentrate prices. At this level of inclusion, the fiber did not significantly reduce performance.

Several methods have been suggested as a means of controlling growth and body weight gain in broiler breeder flocks since these birds have been genetically selected to produce offspring which have a rapid rate of weight gain. For example, for optimal egg production in modern poultry pullets, qualitative and quantitative feed restrictions are commonly used (Leeson and Summers, 1991). Based on the results in this study, date fiber might be used to control the body weight and growth rate in broiler breeder pullets, because this product clearly is of lower energetic value than conventional broiler ration components and does not adversely affect the physiology of the bird. New broiler breeder operations are under construction in Oman. Hence, the work outlined in this report should have application to these industries.

\section{References}

Anonymous. 1997. Analytical study of agricultural systems and evaluation of technical obstacles reflected on the economics of the date sector in the Sultanate of Oman. Ministry of Agriculture and Fisheries Technical Bulletin 97-115:2-67.

Association of Analytical Chemists (AOAC). 1990. Official Methods of Analysis $15^{\text {th }}$ edition. Arlington, VA, USA.

El Hag, M.G. and H.H. El Khanjari. 1992. Dates and sardines as potential animal feed resources. World Animal Review 73:15.

Hussein, A.S., G.A. Alhadrami, and Y.H. Khalil. 1998. The us of dates and date pits in broiler starter and finisher diess. Bioresource Technology 66:219.

Jumah, H.F., I.I. Al-Azzawi, and S.A. Al-Hashimi. 1973. Some nutritional aspects of feeding ground date pits for broilers. Mesopotamia Journal of Agriculture 8:139.

Kamel, B.S., M.F. Diab, M.A. Ilian, and A.J. Salman. 1980. Nutritional value of whole dates and date pits in broiler rations. Poultry Science 60:1005.

Leeson, S. and D.J. Summers, 1991. Commercial Poultry Nutrition. University Books, Toronto, Canada.

SAS Institute. 1991. SAS for Windows (Version 6.0). SAS Institute, Cary, NC.

Sibbald, I.E. 1986. The TME system of feed evaluation; methodology, feed composition data and bibliography. Technical Bulletin 1986-E. Agriculture Canada, Ottawa, Canada. pp 205211.

Vandepopuliere, J.M., Y. Al-Yousef, and J.J. Lyons. 1995. Dates and date pits as ingredients in broiler starting and Coturnix quail breeded diets. Poultry Science 74:1134.

Received 18 January 2000.

Accepted 18 September 2000. 